\title{
DISTURBANCE OF OESTROUS CYCLES IN RATS FOLLOWING ADMINISTRATION OF FREUND'S COMPLETE ADJUVANT
}

\author{
J. R. BATTISTO, M. PINTO* AND S. JOSEPH \\ Department of Biodynamics, \\ Weizmann Institute of Science, Rehovoth, Israel
}

(Received 14th Fanuary 1967)

\begin{abstract}
Summary. Female rats injected with Freund's complete adjuvant in the hind limb footpads had abnormal oestrous cycles characterized by prolonged leucocytic phases. This was observed within 2 days in some animals given adjuvant on the first day of di-oestrus. About one-fourth of the animals with abnormal cycles had the same number of continuous L-days as animals made pseudopregnant by electrical stimulation (11 to 16 days). Although electrical stimulation of the cervix induced pseudopregnancy optimally when applied at pro-oestrus, adjuvant induced pseudopregnancy equally well whether injected at pro-oestrus or dioestrus.
\end{abstract}

Control experiments, conducted during attempts to determine whether decidual tissue has organ-specific antigens, revealed that Freund's complete adjuvant, injected without any uterine or decidual tissue, modified the rat's normal oestrous cycle.

This report draws attention to the fact that the use of adjuvant may throw new light on certain aspects of reproduction. In addition, this information may be useful to investigators of rat arthritic disease (Stoerk, Bielinski \& Budzilovich, 1954; Flax \& Waksman, 1963; Pearson \& Wood, 1964; Formanek, Rosak \& Steffen, 1964).

Three series of experiments were done; data for the first two preliminary series are given in the text, those for the third appear in Table 1. Adult females of the Biodynamics strain (BI, 150 to $218 \mathrm{~g}$ ) and of the Carworth Farms strain (CFN, 190 to $291 \mathrm{~g}$ ) were used. They were maintained in air-conditioned quarters with a 10 to $14 \mathrm{hr}$ light cycle. Vaginal smears were examined daily at 08.00 to 09.00 hours for at least two normal oestrous cycles before treatment and continued throughout the experiment. The normal cycle of the BI strain is 4 days: 1 day of pro-oestrus, 1 of oestrus, and 2 of di-oestrus $\left(\mathrm{O}, \mathrm{Co}, \mathrm{L}_{1}, \mathrm{~L}_{2}\right)$; that of the CFN strain is 5 days $\left(\mathrm{O}, \mathrm{Co}_{1}, \mathrm{Co}_{2}, \mathrm{~L}_{1}, \mathrm{~L}_{2}\right)$. The pseudopregnant rat of both strains has a leucocytic phase of 11 to 16 days.

In the first series of experiments, rats of the BI strain were given saline extracts

* Present address: Department of Microbiology, University of Tel Aviv, Israel. 
of pseudopregnant uterine or decidual tissue, in adjuvant into the hind limb footpads $(0.1 \mathrm{ml}$ in each pad). Two millilitres of the supernatant of tissue extract $(1.5 \mathrm{mg}$ wet wt in $10 \mathrm{ml}$ saline) was emulsified with $5 \mathrm{ml}$ adjuvant.

Nine of twelve females given decidual extract in adjuvant and three of six given decidual-free uterine extract in adjuvant showed oestrous cycles markedly disturbed by prolonged L-phases. This disturbance was not seen in seven females given decidual tissue extract in adjuvant into the dorsal skin.

Rats of Series 2 (also of the BI strain) received tissue-free adjuvant, or Freund's incomplete adjuvant (lacking only mycobacteria) diluted with an equal volume of saline during different phases of the oestrous cycle. Of seven

TABLE 1

EFFECT OF FREUND'S COMPLETE ADJUVANT AND MYGOBACTERIA ON THE OESTROUS GYGLE OF RATS

\begin{tabular}{|c|c|c|c|c|c|c|c|}
\hline $\begin{array}{l}\text { Substance } \\
\text { injected* }\end{array}$ & $\begin{array}{l}\text { Injection } \\
\text { site }\end{array}$ & $\begin{array}{c}\text { Rat } \\
\text { strain } \dagger\end{array}$ & $\begin{array}{c}\text { Injected } \\
\text { at oestrus } \\
\text { or L-phase } \ddagger\end{array}$ & $\begin{array}{l}\text { No. } \\
\text { in } \\
\text { group }\end{array}$ & $\begin{array}{l}\text { Pseudo- } \\
\text { pregnant } \\
\text { response }\end{array}$ & $\begin{array}{l}\text { Decidual } \\
\text { cell } \\
\text { reaction }\end{array}$ & $\begin{array}{l}\text { Oestrous } \\
\text { cycle } \\
\text { disturbed } \$\end{array}$ \\
\hline $\begin{array}{l}\text { Complete } \\
\text { adjuvant } \\
\text { emulsified } \\
\text { with saline }\end{array}$ & $\begin{array}{l}\text { Hind pads } \\
\text { Hind pads } \\
\text { Hind pads } \\
\text { Front pads } \\
\text { Dorsal skin }\end{array}$ & $\begin{array}{l}\text { BI } \\
\text { BI } \\
\text { CFN } \\
\text { CFN } \\
\text { CFN }\end{array}$ & $\begin{array}{l}O \\
L_{1} \\
L_{1} \\
L_{1} \\
L_{1}\end{array}$ & $\begin{array}{l}12 \\
12 \\
16 \\
16 \\
16\end{array}$ & $\begin{array}{l}3 \\
4 \\
3 \\
0 \\
0\end{array}$ & $\begin{array}{l}2 \\
4 \\
2 \\
0 \\
0\end{array}$ & $\begin{array}{r}9 \\
8 \\
10 \\
4 \\
0\end{array}$ \\
\hline $\begin{array}{l}\text { Mycobacterium } \\
\text { butyricum } \\
\text { in saline }\end{array}$ & $\begin{array}{l}\text { Hind pads } \\
\text { Hind pads } \\
\text { Hind pads } \\
\text { Front pads }\end{array}$ & $\begin{array}{l}\text { BI } \\
\text { BI } \\
\text { CFN } \\
\text { CFN }\end{array}$ & $\begin{array}{l}O \\
L_{1} \\
L_{1} \\
L_{1}\end{array}$ & $\begin{array}{r}12 \\
24 \\
24 \\
8\end{array}$ & $\begin{array}{l}0 \\
1 \\
0 \\
0\end{array}$ & $\begin{array}{l}0 \\
0 \\
0 \\
0\end{array}$ & $\begin{array}{l}3 \\
4 \\
0 \\
0\end{array}$ \\
\hline
\end{tabular}

* Each rat injected at two sites, $0.1 \mathrm{ml} / \mathrm{site} ; 50 \mu \mathrm{g}$ of $M$. butyricum/site except for twelve animals of BI strain injected on $L_{1}$ that received $200 \mu \mathrm{g} / \mathrm{site}$.

$\dagger$ Biodynamics departmental (BI) and Carworth Farm, (CFN) strains.

$¥$ Between 10.00 and 15.00 hours.

§ Observed as extra days of L-phase, cornified phase or both.

females given adjuvant into the hind limb footpads on Day 0, five showed prolonged L-phases, three of these lasting for 11 to 16 days.

Twenty-eight of thirty-seven rats or $75 \%$ injected into one footpad with adjuvant on $\mathrm{L}_{1}$ and into the other pad 8 to 11 days later showed abnormal cycles. In each, the L-phase persisted for 5 or more days; three had 27, 32 and 39 L-days. In some of these animals the prolonged L-phase was observable within 2 days of receipt of adjuvant, in others the effect was delayed for one complete cycle or more, and abnormal cycles were occasionally seen to alternate with normal ones.

The effectiveness of the dead mycobacteria in the adjuvant in inducing the altered cycles was revealed by the observation that only two of eighteen females injected into the hind limb footpads with incomplete adjuvant showed any alteration.

To test luteal function in some animals during periods of prolonged L-phase, decidualization of the uterus was induced. This was accomplished on $\mathrm{L}_{4}$ by traumatizing the uterine horns with an intraluminally inserted needle. Deciduomata were looked for 5 days later.

It is of interest that among fifteen adjuvant-treated animals with cycles 
disturbed by L-periods lasting longer than 10 days, eleven had decidual reactions. In none of six animals in which the L-phases were only of 5 to 10 days duration were deciduomata found.

In experiments of Series 3 the investigation was concerned with the effect of adjuvant with regard to site and time of injection, as well as to rat strain differences and to the use of mycobacteria alone. Mycobacteria were injected as saline suspensions $(50 \mu \mathrm{g}$ in $0.1 \mathrm{ml}$ except where otherwise described, see Table 1).

In confirmation of the preliminary experiments, the majority of rats (nine of twelve) of the Biodynamics strain injected with adjuvant into footpads on the day of oestrus showed cycle abnormalities; three had L-phases characteristic of pseudopregnancy and in two of these decidual cell reactions were observed. Of twelve injected on $L_{1}$, eight showed cycle alterations; four had L-periods lasting for 11 to 16 days and deciduomata developed in all four. The results seen among sixteen CFN strain rats injected on $\mathrm{L}_{1}$ were hardly different; ten had altered cycles, three were of pseudopregnancy duration and of these two showed decidual responses.

When deposited in sites other than footpads, the effect of adjuvant was much less. Thus, only four of sixteen GFN animals receiving adjuvant into front pads showed disturbed cycles and all sixteen CFN rats injected with adjuvant into the dorsal skin remained normal.

Experiments of Series 2 had revealed that adjuvant without mycobacteria had little effect on the cycles. In Series 3 , mycobacteria alone, i.e. without mineral oil and emulsifier, also had little effect. Only three of twelve BI rats receiving the bacteria into hind pads on Day 0 showed interference with their cycles. Of twenty-four injected with mycobacteria at L-phase, four had erratic cycles and only one of these was pseudopregnant. (Twelve animals of this group of twenty-four received $200 \mu \mathrm{g}$ of $M$. butyricum/footpad, but the incidence of disturbance of the cycle was not increased.) None of GFN rats given $50 \mu \mathrm{g}$ of $M$. butyricum/hind footpad and none of eight given the same quantity/front footpad at L-phase showed cycle abnormalities. Thus, adjuvant is superior to either incomplete adjuvant or the mycobacteria alone in producing alterations in the oestrous cycle and the most effective site is the hind footpad.

The most marked change brought about by adjuvant is a persistence of leucocytes in the vaginal smear and less frequently there is prolongation of the cornified phase. Among animals with disturbed cycles $25 \%$ had L-phases equal to those of rats in pseudopregnancy. As the physiological state of pseudopregnancy can be induced by a variety of stimuli (Lataste, 1887; Long \& Evans 1922; Shelesnyak, 1931; Swingle, Seay, Perlmutt, Collins, Barlow \& Fedor, 1951; and Psychoyos, 1959) it is reasonable to assume that the pseudopregnancy induced by adjuvant is also stress-induced. However, the production of cycle irregularities in rats that were not pseudopregnant still requires explanation.

An immunological mechanism might provide an alternate explanation for the prolonged appearance of leucocytes in vaginal smears. This is suggested because leucocytes have been found in the vagina during the normal oestrous cycles of germ-free rats (J. R. Battisto and S. Scher, unpublished results). 
If the leucocytes are present in response to altered autologous tissue antigens and not to bacterial flora, then adjuvant would serve to heighten the immunological activity of the leucocytes and prolong their appearance in vaginal contents. Because the 2- or 4-day interval within which the cycle alterations can be observed is too short an interval for full development of hypersensitivity de novo, the sensitivity for autologous antigens would have to be present in some animals before receipt of adjuvant.

Waksman \& Wennerstein (1963) and Pearson \& Wood (1964) have provided evidence that induction of arthritis and of other lesions in rats by adjuvant is brought about by initiating a delayed-type hypersensitivity. Though the responsible antigen of the rat was not identified in their studies, the earliest symptoms they observed followed a full immunological period (10 to 14 days).

The optimal time during an oestrous cycle for inducing pseudopregnancy by adjuvant was found to be different from the best time for inducing pseudopregnancy by other means. For instance, electrical stimulation of the cervix induces pseudopregnancy best when applied at pro-oestrus whereas adjuvant was effective whether given at pro-oestrus or di-oestrus.

The senior author is indebted to Dr Kenneth A. Laurence, Assistant Director of the Population Council, for his aid with sabbatical arrangements and to Professor M. C. Shelesnyak, for his generosity in making available laboratory facilities essential to the pursuit of this study as well as for informative discussions held throughout the period of a year. He thanks Dr George Marcus and Dr Peretz Kraicer for many kindnesses, Mr Shalom Joseph for assistance with animals and $\mathrm{Mr}$ Yehoshua Shamash for care of equipment.

This work was supported in part by a grant-in-aid from the Population Council Inc., New York. One of us (J.R.B.) is on Sabbatical leave from the Department of Microbiology and Immunology, Albert Einstein College of Medicine, Yeshiva University, New York 61, as a Senior Research Fellow of the Population Council Inc., New York.

\section{REFERENCES}

Flax, M. H. \& Waksman, B. H. (1963) Further immunologic studies of adjuvant disease in the rat. Int. Archs Allergy appl. Immun. 23, 331.

Formanek, K., Rosak, M. \& Stefren, C. (1964) Weitere Untersuchungen uber die experimentelle Adjuvants-Arthritis der Ratte. Int. Archs Allergy appl. Immun. 24, 39.

LATASTE, F. (1887) Recherches der Zooethique sur les mamifères de l'ordre. Ed. Rongeurs. J. Durand, Bordeaux.

Long, J. A. \& Evans, H. M. (1922) The oestrous cycle in the rat and its associated phenomena. Memoir of the University of California.

Pearson, C. M. \& Wood, F. D. (1964) Passive transfer of adjuvant arthritis by lymph node or spleen cells. F. exp. Med. 120, 547 .

Psychoyos, A. (1959) Induction of pseudopregnancy and deciduomata in the rat by hypertonic solutions. Memoirs of the Society for Endocrinology No. 6, p. 13. Cambridge University Press.

Shelesnyak, M. C. (1931) The induction of pseudopregnancy in the rat by means of electrical stimulation. Anat. Rec. 49, 179.

Stoerk, H. C., Bielinski, T. C. \& Budzilovich, T. (1954) Chronic polyarthritis in rats injected with spleen in adjuvants. Am. F. Path. 30, 616.

Swingle, W. W., Seay, P., Perlmutt, J., Collins, E. J., Barlow, G. \& Fedor, E. J. (1951) An experimental study of pseudopregnancy in the rat. Am. F. Physiol. 167, 586.

Waksman, B. H. \& Wennerstein, C. (1963) Passive transfer of adjuvant arthritis in rats with living lymphoid cells of sensitized donors. Int. Archs Allergy appl. Immun. 23, 129. 